\title{
Differing requirements for capacitation in vitro of mouse spermatozoa from two strains
}

\author{
Lynn R. Fraser \\ Clinical Research Centre, Watford Road, Harrow, Middlesex, HAl 3UJ \\ and \\ Department of Obstetrics and Gynaecology, University College Hospital, \\ London, WCIE 6DH, U.K.
}

\begin{abstract}
Summary. Concentrated suspensions of epididymal spermatozoa obtained from two strains of mice, TO and C57BL/10, were preincubated for $20 \mathrm{~min}, 1 \mathrm{~h}$ or $2 \mathrm{~h}$ before dilution and addition of $(\mathrm{C} 57 \mathrm{BL} / 10 \times \mathrm{CBA}) \mathrm{F}_{1}$ eggs. While all 3 groups of TO spermatozoa demonstrated high fertility ( $>90 \%$ of eggs subsequently cleaved), C57BL/10 spermatozoa preincubated for $20 \mathrm{~min}$ and $1 \mathrm{~h}$ gave significantly reduced fertilization rates compared with those in the $2 \mathrm{~h}$ group. Furthermore, the penetration rate of the C57BL/10 spermatozoa preincubated for $20 \mathrm{~min}$ was significantly slower than that for similarly treated TO spermatozoa, as demonstrated by a delay in the first cleavage. A long preincubation of $\mathrm{C} 57 \mathrm{BL} / 10$ spermatozoa in a diluted rather than a concentrated suspension did not improve fertility, suggesting that optimal capacitation may be sperm concentration-dependent in some, if not all, strains of mice.
\end{abstract}

\section{Introduction}

If capacitation occurs in the mouse, it is a relatively rapid process in vivo, because when mating is delayed until ovulation is completed sperm penetration can be detected as early as $1 \mathrm{~h}$ after mating (Braden \& Austin, 1954; Bryan, 1974; Krzanowska, 1964). Various studies, employing a variety of media and strains of mice, have suggested that capacitation in vitro of mouse spermatozoa requires 1-3 h (Hoppe \& Whitten, 1974; Iwamatsu \& Chang, 1969, 1970; Miyamoto \& Chang, 1973; Oliphant \& Brackett, 1973; Toyoda, Yokoyama \& Hosi, 1971).

Recently Fraser \& Drury (1976) reported a difference in the penetration rates in vitro of spermatozoa from two different strains of mice into eggs from one strain, suggesting that the time required for capacitation in the two strains differed. Spermatozoa from outbred TO mice were able to complete penetration (fusion with vitellus) of $(\mathrm{C} 57 \mathrm{BL} / 10 \times \mathrm{CBA}) \mathrm{F}_{1}$ eggs within $1.5 \mathrm{~h}$, while $\mathrm{F}_{1}$ spermatozoa required $2.5 \mathrm{~h}$ to complete penetration of $F_{1}$ eggs. Spermatozoa allowed to disperse for only $20 \mathrm{~min}$ were able to attach to and fertilize eggs and, despite the difference in penetration rates, fertilization rates (no. of 2-cell embryos/no. of eggs, after $24 \mathrm{~h}$ ) were high. In the present experiments a third strain of mouse, C57BL/10, was used as a sperm donor and the results suggest that this strain differs significantly from the above two in the ability of the spermatozoa to interact successfully with $F_{1}$ eggs.

\section{Materials and Methods}

All mice were supplied by the Specific Pathogen Free breeding unit at the Clinical Research Centre. Unfertilized eggs were obtained from 2-4-month-old (C57BL/10 $\times$ CBA) $F_{1}$ females induced to superovulate by an injection of 7.5 i.u. PMSG (Gestyl: Organon) followed, approximately $48 \mathrm{~h}$ later, by 5 i.u. HCG (Pregnyl: Organon). Media and dishes were prepared as described by Fraser \& Drury (1975). Spermatozoa were obtained from 2-4-month-old outbred TO and C57BL/10 males. 
Concentrated sperm suspensions were prepared by extrusion of the contents of one epididymis and vas deferens from each of two TO males or both epididymides and vasa deferentia of two C57BL/10 males into $1 \mathrm{ml}$ fertilization medium (Fraser \& Drury, 1975). It was necessary to use all four epididymides of the C57BL/10 males to obtain a sperm concentration similar to that obtained with two TO epididymides.

\section{Series $I$}

Both sperm suspensions were allowed to disperse for $20 \mathrm{~min}$, during which time they were maintained at $37^{\circ} \mathrm{C}$ in an atmosphere of $5 \% \mathrm{O}_{2}+5 \% \mathrm{CO}_{2}+90 \% \mathrm{~N}_{2}$. Each suspension was then mixed thoroughly by gentle pipetting. An aliquot was removed from each and diluted 1:9 to give a final concentration of 1.6-2.7 $\times 10^{6}$ spermatozoa $/ \mathrm{ml}$. The concentrated suspensions were incubated for a further period, with aliquots removed 1 and $2 \mathrm{~h}$ after initial release of spermatozoa and diluted as above.

Unfertilized eggs were released from oviducts into the diluted suspensions. To avoid effects that ageing of eggs might introduce, $\mathrm{HCG}$ was given at different times so that all eggs were obtained $13 \mathrm{~h}$ after the HCG injection. The experimental design was such that in each sperm group $(20 \mathrm{~min}, 1 \mathrm{~h}$, $2 \mathrm{~h}$ ) the dish of TO spermatozoa received the contents of one oviduct from each female used at that time and the C57BL/10 spermatozoa received those of the other oviduct. Thus the eggs in parallel dishes were as equivalent as possible.

\section{Series $I I$}

The effect of a long preincubation of C57BL/10 spermatozoa in a diluted suspension was compared with that of a similar preincubation in a concentrated suspension. The sperm concentration of the suspensions ranged from $1.8-2.6 \times 10^{7} / \mathrm{ml}$ and was finally adjusted to $2 \cdot 0 \times 10^{6} / \mathrm{ml}$ in all dishes. Again, two males were used and the suspension prepared as described above. After a 20-min dispersal period, an aliquot was removed, diluted and divided between two dishes $(0.5 \mathrm{ml}$ each). Unfertilized eggs were added immediately to one dish. The other dish, containing diluted spermatozoa, and the original concentrated suspension were incubated for $1 \mathrm{~h} 40 \mathrm{~min}$ (total period of incubation from time of sperm release $=2 \mathrm{~h}$ ). An aliquot of the concentrated sperm suspension was then diluted and unfertilized eggs obtained $13 \mathrm{~h}$ after HCG injection were released into both suspensions.

After $6 \mathrm{~h}$ all eggs were removed from the sperm suspensions, washed twice and cultured (Fraser $\&$ Drury, 1975). The culture rates were determined by examining for cleavage at $24-\mathrm{h}$ intervals. The number of blastocysts obtained after 5 days in culture was used to calculate the culture rate.

Cochran's test for combination of $2 \times 2$ contingency tables was used for statistical analysis of the results (Snedecor \& Cochran, 1967).

\section{Results}

\section{Series $I$}

Although there was no adjustment to equalize the final concentrations of $\mathrm{TO}$ and $\mathrm{C57BL} / 10$ spermatozoa, the two concentrations were similar in all experiments (Table 1) and fell within the range expected to give a high fertilization rate (Fraser \& Drury, 1975). When TO spermatozoa were preincubated for $20 \mathrm{~min}, 1 \mathrm{~h}$ or $2 \mathrm{~h}$ before dilution and addition of eggs, there were no significant differences among the groups $(P>0.05)$ and the mean fertilization rates were all $\geqslant 90 \%$. The results with the $\mathrm{C} 57 \mathrm{BL} / 10$ spermatozoa differed. There was no significant difference for the 20 min and $1 \mathrm{~h}$ preincubations $(P>0.05)$, but there was a highly significant increase in the rate of fertilization when the spermatozoa were preincubated for $2 \mathrm{~h}$ before dilution $(P<0.001)$. Even after $2 \mathrm{~h}$ the fertility of the C57BL/10 spermatozoa was lower than that of TO spermatozoa. No attempt was made to extend the preincubation period beyond $2 \mathrm{~h}$ since increased agglutination of spermatozoa has been noted in suspensions maintained for several hours (unpublished observation), 
Table 1. Fertilization in vitro (no. of 2-cell embryos/total no. of eggs) of $\mathrm{F}_{1}$ mouse eggs with TO and C57BL/10 spermatozoa preincubated in concentrated suspensions for various times

\begin{tabular}{|c|c|c|c|c|c|c|c|}
\hline \multirow[b]{2}{*}{ Exp. } & \multirow{2}{*}{$\begin{array}{l}\text { Sperm conc. } \\
\left(\times 10^{6} / \mathrm{ml}\right)\end{array}$} & \multicolumn{6}{|c|}{ Preincubation period } \\
\hline & & $20 \mathrm{~min}$ & $(\%)$ & $1 \mathrm{~h}$ & $(\%)$ & $2 \mathrm{~h}$ & $(\%)$ \\
\hline 1 & $\begin{array}{l}\text { To }=2 \cdot 1 \\
\text { C57BL/10 }=2 \cdot 2\end{array}$ & $\begin{array}{l}37 / 38 \\
39 / 50\end{array}$ & $\begin{array}{l}(97) \\
(78)\end{array}$ & $\begin{array}{l}43 / 43 \\
31 / 49\end{array}$ & $\begin{array}{r}(100) \\
(63)\end{array}$ & $\begin{array}{l}51 / 61 \\
35 / 44\end{array}$ & $\begin{array}{l}(84) \\
(83)\end{array}$ \\
\hline 2 & $\begin{array}{l}\text { To }=1.8 \\
\text { C56BL/10 }=1.6\end{array}$ & $\begin{array}{l}49 / 55 \\
15 / 42\end{array}$ & $\begin{array}{l}(89) \\
(36)\end{array}$ & $\begin{array}{l}46 / 46 \\
22 / 44\end{array}$ & $\begin{array}{r}(100) \\
(50)\end{array}$ & $\begin{array}{l}29 / 33 \\
23 / 34\end{array}$ & $\begin{array}{l}(88) \\
(68)\end{array}$ \\
\hline 3 & $\begin{array}{ll}\text { TO } & =2 \cdot 7 \\
\text { C } 57 \mathrm{BL} / 10 & =2 \cdot 1\end{array}$ & $\begin{array}{l}28 / 29 \\
20 / 33\end{array}$ & $\begin{array}{l}(97) \\
(61)\end{array}$ & $\begin{array}{l}47 / 52 \\
33 / 53\end{array}$ & $\begin{array}{l}(90) \\
(62)\end{array}$ & $\begin{array}{l}35 / 36 \\
19 / 26\end{array}$ & $\begin{array}{l}\text { (97) } \\
(73)\end{array}$ \\
\hline 4 & $\begin{array}{ll}\text { TO } & =2 \cdot 3 \\
\text { C57BL } / 10 & =2 \cdot 1\end{array}$ & $\begin{array}{l}58 / 62 \\
22 / 44\end{array}$ & $\begin{array}{l}(94) \\
(50)\end{array}$ & $\begin{array}{l}41 / 45 \\
21 / 46\end{array}$ & $\begin{array}{l}(91) \\
(46)\end{array}$ & $\begin{array}{l}55 / 59 \\
32 / 40\end{array}$ & $\begin{array}{l}\text { (93) } \\
\text { (80) }\end{array}$ \\
\hline Total & $\begin{array}{l}\text { TO } \\
\text { C57BL/10 }\end{array}$ & $\begin{array}{r}172 / 184 \\
96 / 169\end{array}$ & $\begin{array}{l}(93) \\
(57)\end{array}$ & $\begin{array}{l}177 / 186 \\
107 / 192\end{array}$ & $\begin{array}{l}(95) \\
(56)\end{array}$ & $\begin{array}{l}170 / 189 \\
109 / 144\end{array}$ & $\begin{array}{l}(90) \\
(76)\end{array}$ \\
\hline Culture rate* & $\begin{array}{l}\text { TO } \\
\text { C57BL/10 }\end{array}$ & $\begin{array}{c}147 / 172 \\
78 / 96\end{array}$ & $\begin{array}{l}(85) \\
(81)\end{array}$ & $\begin{array}{r}141 / 177 \\
81 / 107\end{array}$ & $\begin{array}{l}(80) \\
(76)\end{array}$ & $\begin{array}{r}141 / 170 \\
82 / 109\end{array}$ & $\begin{array}{l}(83) \\
(75)\end{array}$ \\
\hline
\end{tabular}

* No. of blastocysts/no. of 2-cell embryos.

There were no significant differences among the culture rates of embryos obtained following fertilization with the two different strains of spermatozoa, but in several experiments cleavage to the 2-cell stage was slightly delayed with some eggs still being pronuclear at the time of assessment for first cleavage ( $24 \mathrm{~h}$ after mixing of eggs and spermatozoa). A low frequency of delay was found in the three groups of TO spermatozoa ( $1 \%$ at $20 \mathrm{~min}, 2 \%$ at $1 \mathrm{~h}, 2 \%$ at $2 \mathrm{~h}$ ), but there was a significantly increased incidence with C57BL/10 spermatozoa preincubated for $20 \mathrm{~min}(12 \%, P<0.001)$ and $1 \mathrm{~h}$ $(9 \%, P<0.01)$, when compared with the corresponding TO group. The values for TO $(2 \%)$ and C57BL/10 (4\%) spermatozoa preincubated for $2 \mathrm{~h}$ did not differ significantly. These results suggest that although spermatozoa from C57BL/10 mice can fertilize $F_{1}$ eggs when incubated for $<2 \mathrm{~h}$, their rate of penetration is relatively slower than for either TO spermatozoa similarly incubated or C57BL/10 spermatozoa incubated for a longer time. There was no indication that these eggs were activated rather than fertilized: all had second polar bodies and their subsequent preimplantation development to the blastocyst stage was similar to that of the $F_{1}$ eggs fertilized with TO spermatozoa. Activated $F_{1}$ eggs aged in vivo generally cease development at the 2-cell stage when cultured in the manner described here (unpublished observation).

\section{Series $I I$}

The results are presented in Table 2. Again, C57BL/10 spermatozoa preincubated for $20 \mathrm{~min}$ fertilized significantly fewer eggs than those preincubated in a concentrated suspension for $2 \mathrm{~h}$ $(P<0.01)$. The suspensions which had been diluted after $20 \mathrm{~min}$ and incubated further for a total of $2 \mathrm{~h}$ gave significantly reduced fertilization rates when compared with those of concentrated suspensions preincubated for $20 \mathrm{~min}(P<0.01)$ and $2 \mathrm{~h}(P<0.001)$. There was greater variability among the results from the 3 experiments using $2 \mathrm{~h}$ diluted spermatozoa than with the other two groups of spermatozoa, although there was no detectable difference in sperm motility. There was no significant difference in the culture rates obtained with the different spermatozoa.

\section{Discussion}

The present results indicate that outbred TO spermatozoa do not require extensive preincubation to become capacitated and capable of fertilizing eggs in vitro. The similar fertilization rates obtained with preincubations from $20 \mathrm{~min}$ to $2 \mathrm{~h}$ are consistent with those of an earlier study demonstrating that TO sperm penetration can occur within 30 min of dilution and mixing with eggs (Fraser \& Drury, 1976). When C57BL/10 spermatozoa were similarly preincubated and mixed with eggs from the same 
females, the longest period of $2 \mathrm{~h}$ significantly increased the fertilization rate. This suggests that capacitation of C57BL/10 spermatozoa, defined as the ability of the spermatozoa to penetrate eggs, is favoured by a long preincubation time as has been reported for other strains.

Table 2. Fertilization in vitro (no. of 2 -cell embryos/total no. of eggs) of $F_{1}$ mouse eggs with C57BL/10 spermatozoa preincubated in concentrated or diluted suspensions

\begin{tabular}{ccccccc}
\hline & \multicolumn{5}{c}{ Preincubation period } \\
\cline { 2 - 7 } Exp. & $\begin{array}{c}20 \text { min } \\
\text { (concentrated) }\end{array}$ & $(\%)$ & (concentrated) & $(\%)$ & (diluted) & $(\%)$ \\
\hline 1 & $26 / 42$ & $(57)$ & $56 / 78$ & $(72)$ & $7 / 51$ & $(14)$ \\
2 & $15 / 26$ & $(58)$ & $32 / 46$ & $(70)$ & $13 / 30$ & $(43)$ \\
3 & $23 / 36$ & $(64)$ & $41 / 44$ & $(93)$ & $35 / 52$ & $(67)$ \\
Total & $62 / 104$ & $(60)$ & $129 / 168$ & $(77)$ & $55 / 133$ & $(41)$ \\
Culture rate* & $49 / 62$ & $(77)$ & $107 / 129$ & $(83)$ & $44 / 55$ & $(80)$ \\
\hline
\end{tabular}

* No. of blastocysts/no. of 2-cell embryos.

Krzanowska (1964) has reported differences in vivo in sperm penetration rates, time of extrusion of the second polar body and appearance of pronuclei when inbred, $F_{1}$ and outbred strains were compared, these events being slower in the inbred strains. Although care must be used in interpreting results obtained following mating, because of possible variations in sperm transport for example, the findings are consistent with those presented here in suggesting that differences in capacitation times among strains do exist.

From the present study and that of Fraser \& Drury (1976), it would appear that at least 3 patterns of mouse sperm capacitation can be detected in vitro. These patterns may well reflect genetic differences among the strains since eggs from the same mouse strain have been used throughout to test the fertilizing ability of the spermatozoa. With the first pattern (e.g. TO spermatozoa), a short preincubation long enough to allow dispersal and attainment of maximum motility (Pavlok \& McLaren, 1972) is sufficient to give a rapid penetration rate and a high fertilization rate. With the second ( $F_{1}$ spermatozoa), a short preincubation is again sufficient to give a high fertilization rate although the penetration rate is considerably slower than the first group. In contrast, with the third pattern (C57BL/10 spermatozoa) there is reduced and delayed fertilization when dilution occurs after a short preincubation. These spermatozoa are less successful in interacting with eggs than those from TO and $F_{1}$ males similarly treated, although a long preincubation of the C57BL/10 spermatozoa improves their fertility.

Since extended incubation of C57BL/10 spermatozoa in a concentrated suspension gives significantly better results than similar treatment in a diluted suspension, a cooperative effect may exist during capacitation of at least the $\mathrm{C} 57 \mathrm{BL} / 10$ and perhaps all mouse spermatozoa. A concentrated suspension of spermatozoa would not appear to be necessary for all strains since $F_{1}$ spermatozoa show high fertility when diluted after $20 \mathrm{~min}$ (a high proportion of the eggs subsequently cleave), although penetration of eggs to a significant extent does not occur for $2 \mathrm{~h}$ after mixing of gametes (Fraser \& Drury, 1976). It is possible that the concentration of morphologically normal spermatozoa, i.e. those presumably able to become capacitated and successfully fertilize eggs, is a critical factor in determining the rate at which capacitation occurs. Because C57BL/10 sperm suspensions generally contain fewer morphologically normal spermatozoa than either $F_{1}$ or TO suspensions (unpublished observation), this might explain the apparent concentration dependence of these spermatozoa for capacitation and the lower fertility in vitro. Beatty \& Sharma (1960) and Brózek (1970) have also found a relatively high incidence of abnormal spermatozoa in C57BL mice when compared with other strains. In the present study significantly different results were obtained from single suspensions of C57BL/10 spermatozoa, depending on the length of preincubation before dilution, and yet the diluted suspensions, whether prepared after $20 \mathrm{~min}$ or $2 \mathrm{~h}$, should have contained the same proportion of abnormal spermatozoa. This suggests that the primary factor involved in the differing fertility 
rates is not morphological normality per se, but rather some interaction which occurs during the extended preincubation period.

The requirements for capacitation in vitro of mouse and rat spermatozoa appear to differ. In the rat, maximum capacitation, as shown by fertilization, is obtained by a long preincubation in a diluted $\left(0.7-1.2 \times 10^{6} / \mathrm{ml}\right)$ rather than a concentrated $\left(0.9-1.5 \times 10^{7} / \mathrm{ml}\right)$ suspension (Niwa \& Chang, 1974). The present experiments demonstrate that a long preincubation of mouse spermatozoa in a concentrated $\left(2 \times 10^{7} / \mathrm{ml}\right)$ suspension has no deleterious effect and may well increase the fertility.

I thank Mrs Linda Drury for expert technical assistance.

\section{References}

Beatty, R. \& Sharma, K. (1960) Genetics of gametes. III. Strain differences in spermatozoa from eight inbred strains of mice. Proc. R. Soc. Edin. B 68, 2553.

Braden, A. \& Austin, C. (1954) Fertilization of the mouse egg and the effect of delayed coitus and of hot-shock treatment. Aust. J. biol. Sci. 7, 552565.

BrỏzeK, C. (1970) Proportion of morphologically abnormal spermatozoa in two inbred strains of mice, their reciprocal $F_{1}$ and $F_{2}$ crosses and backcrosses. Acta biol. crac., Ser. Zool. 13, 189-199.

Bryan, J. (1974) Capacitation in the mouse: the response of murine acrosomes to the environment of the female reproductive tract. Biol. Reprod. 10, 414421.

FrASER, L. \& DrURY, L. (1975) The relationship between sperm concentration and fertilization in vitro of mouse eggs. Biol. Reprod. 13, 513-518.

Fraser, L. \& DRURY, L. (1976) Mouse sperm genotype and the rate of egg penetration in vitro. J. exp. Zool. 197, 13-20.

Hoppe, P. \& Whitten, W. (1974) Maturation of mouse sperm in vitro. J. exp. Zool. 188, 133-136.

IWAMATSU, T. \& ChaNG, M. (1969) In vitro fertilization of mouse eggs in the presence of bovine follicular fluid. Nature, Lond. 224, 919-920.
Iwamatsu, T. \& Chang, M. (1970) Further investigation of capacitation of sperm and fertilization of mouse eggs in vitro. J. exp. Zool. 175, 271-282.

KrzanowsKA, H. (1964) Time interval between copulation and fertilization in inbred lines of mice and their crosses. Folia biol., Krakow 12, 231--244.

Mixamoto, H. \& Chang, M. (1973) The importance of serum albumin and metabolic intermediates for capacitation of spermatozoa and fertilization of mouse eggs in vitro. J. Reprod. Fert. 32, 193-205.

NiWA, K. \& Chang, M. (1974) Effects of sperm concentration on the capacitation of rat spermatozoa. J. exp. Zool. 189, 353-356.

Oliphant, G. \& BracketT, B. (1973) Capacitation of mouse spermatozoa in media with elevated ionic strength and reversible decapacitation with epididymal extracts. Fert. Steril. 24, 948-955.

Pavlok, A. \& McLaren, A. (1972) Role of cumulus cells and the zona pellucida in fertilization of mouse eggs in vitro. J. Reprod. Fert. 29, 91-97.

SNEDECOR, G. \& COCHRAN, W. (1967) Statistical Methods, 6 th edn. Iowa State University Press, Ames, Iowa.

Toyoda, Y., Yokoyama, M. \& Hosi, T. (1971) Studies on the fertilization of mouse eggs in vitro. II. Effects of in vitro preincubation of spermatozoa on time of sperm penetration, of mouse eggs in vitro. Jap. $J$. Anim. Reprod. 16, 152-157.

Received 3 July 1976 